\title{
38. TEMPERATURE OF FORMATION AND ISOTOPIC COMPOSITION OF CARBON AND OXYGEN OF CARBONATE VEINS IN BASALTS, DEEP SEA DRILLING PROJECT SITES 443 AND 446
}

\author{
G. V. Nisterenko, L. A. Bannikova, L. S. Medvedeva, and V. B. Naumov, Vernadsky Institute of Geochemistry \\ and Analytical Chemistry, U.S.S.R. Academy of Sciences, Moscow
}

\begin{abstract}
The temperature of carbonate-vein formation in basalts in the Shikoku Basin and Daito Ridge (Philippine Sea) is below $50^{\circ} \mathrm{C}$. This, along with oxygen-isotope data, points to carbonate deposition in basalts from cold sea waters (DSDP Site 443) and interstitial waters (DSDP Site 446).
\end{abstract}

\section{INTRODUCTION}

Basalts in the Shikoku Basin (DSDP Sites 442 and 443) and Daito Ridge (Site 446) are characterized by thin (as much as $2 \mathrm{~mm}$ ) carbonate veins, commonly with pyrite. Veins which are occasionally quartz-carbonate reaching $10 \mathrm{~mm}$ and more in thickness are an exception at Site 446. Also encountered there were clastic dikes, actually a slightly altered aggregate of fine fragmentary material filling fracture zones in basalts and cemented by quartz or a quartz-carbonate mass. It is of interest that the carbonate veins contain native copper (as at $443-54-3,108 \mathrm{~cm}$ ), which has attracted our attention to the problem of source and temperature of solutions which formed the carbonate veins. This task has been solved by fluid-inclusion investigation and by oxygenand carbon-isotope methods.

Carbonate veins in basalts of Hole 443 (Shikoku Basin) and Hole 446A (Daito Ridge) were studied. These were formed in different geological environments. The Shikoku basalts are flows of the Philippine Sea floor, which were in direct and continuous contact with ocean water. The Daito Ridge basalts are sills intruded into the sequence of Eocene sedimentary rocks and could, therefore, have interacted only with interstitial waters of the sediments. This fact is essential to the interpretation of the data.

To determine temperatures of carbonate-vein formation, all the samples collected for analysis (Table 1) were checked for fluid inclusions. These were found in four of the 11 samples. These are one-phase liquid inclusions with acicular crystals of a non-metallic mineral (zeolite?) or crystals of an ore mineral (pyrite?). Because there is no gas phase in the fluid inclusions, we cannot determine narrow temperature ranges of the solutions essential to interpretation of equilibrium isotopic ratios of the carbonates. At the same time, this clearly points to low temperatures (below $50^{\circ} \mathrm{C}$ ) of the solutions which formed carbonate veins in the basalts.

\section{RESULTS}

The oxygen-isotope composition in carbonates from Hole 443 varies from +30.0 to +33.7 per mill, and the carbon-isotope composition varies from -3.2 to +2 per mill. Samples from Hole 446A have lower $\delta^{18} \mathrm{O}$ values $(+25.9$ to $+27.4 \%$ ), and carbon-isotope composition similar to that for Hole $443\left(\delta^{13} \mathrm{C}-3.1\right.$ to $2.3 \%$; Table 1).

Since there are no exact temperatures of carbonate deposition, the obtained results fail to give a direct answer to the question of the source of solutions which formed the carbonate veins. We can generally identify these plausible sources: (1) magmatic water from degassing of a basalt melt, (2) oceanic water, (3) interstitial water of sedimentary rocks.

Proceeding from the assumption that magmatic water expelled from a basalt mass was the solution source, the temperature of solutions which formed the carbonate veins of Hole $446 \mathrm{~A}$ should be above $50^{\circ} \mathrm{C}$ (Table 1); (O'Neil et al., 1969). This is at variance with direct determination of solution temperatures by fluid inclusions; thus, magmatic water is excluded as a possible solution source. This agrees with the ideas of Anderson (1973) on the small volumetric significance of magmatic waters compared with interstitial waters in submarine rock alteration.

As is evident from Table 1, calculated equilibrium temperatures of carbonate-vein deposition $\left(0.8-15^{\circ} \mathrm{C}\right)$ correspond to those of near-bottom ocean water $\left(\delta^{18} \mathrm{O}\right.$ $=0 \%$ ). This agrees well with the mode of basalt emplacement in the Shikoku Basin (Hole 443); lavas effusing onto the sea floor were rapidly cooled.

Carbonates might have been deposited from interstitial waters $\left(\delta^{18} \mathrm{O}=-1.2 \%\right.$; Anderson, 1973) only at Site 446 , where basalts have intruded as sills into the sequence of sedimentary rocks, failing, therefore, to ensure direct contact with ocean water. The equilibrium temperatures of carbonate deposition $\left(22-29^{\circ} \mathrm{C}\right)$ agree 
TABLE 1

Isotopic Composition of Carbonate Veins in Basalts, DSDP Sites 443 and 446

\begin{tabular}{|c|c|c|c|c|c|c|}
\hline \multirow[b]{3}{*}{$\begin{array}{c}\text { Sample } \\
\text { (interval in } \mathrm{cm} \text { ) }\end{array}$} & \multirow{2}{*}{\multicolumn{2}{|c|}{$\begin{array}{l}\text { Isotopic Com- } \\
\text { position of } \\
\text { Carbonates }\end{array}$}} & \multicolumn{3}{|c|}{ Source and Calculated Temperature $\left({ }^{\circ} \mathrm{C}\right)$ of Solutions } & \multirow[b]{3}{*}{$\begin{array}{c}\text { Solution Temperature from } \\
\text { Fluid Inclusions }\end{array}$} \\
\hline & & & \multirow{2}{*}{$\begin{array}{l}\text { Oceanic Water } \\
\delta^{18} \mathrm{O}_{\mathrm{H}_{2} \mathrm{O}}=0 \% \\
(\mathrm{SMOW})\end{array}$} & \multirow{2}{*}{$\begin{array}{c}\text { Interstitial } \\
\text { Water } \\
\delta 18 \mathrm{O}_{\mathrm{H}_{2} \mathrm{O}}=-1.2 \% \\
\text { (SMOW) }\end{array}$} & \multirow{2}{*}{$\begin{array}{c}\text { Magmatic } \\
\text { Water } \\
\delta 18 \mathrm{O}_{\mathrm{H}_{2} \mathrm{O}}=+6 \% \\
\text { (SMOW) }\end{array}$} & \\
\hline & $\begin{array}{l}\delta^{13} \mathrm{C} \\
(\mathrm{PDB}) \\
(\% \circ)\end{array}$ & $\begin{array}{c}\delta^{180} \\
(\mathrm{SMOW}) \\
(\%)\end{array}$ & & & & \\
\hline $443-50-1,52-57$ & -0.8 & +33.4 & +2 & $<0$ & 27 & $<50^{\circ} \mathrm{C}$ (zeolite?) \\
\hline $53-2,56-59$ & +0.4 & +33.2 & +3 & $<0$ & 27 & - \\
\hline $53-2,71-76$ & +1.3 & +32.2 & +6 & +2 & 33.5 & $<50^{\circ} \mathrm{C}$ \\
\hline $56-4,23-26$ & +1.4 & +32.9 & +4 & $<0$ & 33 & - \\
\hline $57-1,90-103$ & +2.0 & +33.5 & +1.5 & $<0$ & 27 & - \\
\hline $59-2,81-86$ & +1.3 & +33.7 & +0.8 & $<0$ & 27 & - \\
\hline $59-5,90-95$ & -3.2 & +30.0 & +15 & +10 & 46 & - \\
\hline $61-2,81-84$ & +1.4 & +33.5 & +1.5 & $<0$ & 27 & - \\
\hline $446 \mathrm{~A}-4-1,67-71$ & -3.1 & +25.9 & - & +29 & +52 & $<50^{\circ} \mathrm{C}$ (pyrite?) \\
\hline $12-2,92-102$ & +0.2 & +26.8 & - & +25 & +82 & - \\
\hline $13-2,32-40$ & +2.3 & +27.4 & - & +22 & +107 & $<50^{\circ} \mathrm{C}$ \\
\hline
\end{tabular}

well with the results of fluid-inclusion investigation. The high values, compared with those for Hole 433, can easily be accounted for by the fact that sediments into which the basalts have intruded hampered heat removal.

Table 1 also shows that carbonate veins should have formed in Hole 443 basalts prior to sedimentation, because, if we assume that carbonates are formed from interstitial waters, their deposition temperatures should be negative.

Thus, these data show that carbonates were deposited in Hole 443 basalts from cold sea water, and in Hole 446A basalts from interstitial waters.

This interpretation is supported by the agreement of the isotopic composition of carbon in the veins with values typical of sedimentary carbonates. The lightisotope content increases for a number of samples, apparently because of organic-matter oxidation (Douglas and Savin, 1975; Denser et al., 1978; Brenneke, 1978).

Carbonate-vein formation in ocean basalts is generally a result of interaction with sea water, which may involve radical changes in rock composition (Sheppard et al., 1977; Javoy and Pineau, 1977). Along with rockforming minerals, sulfides, represented in basalts by pyrite, chalcopyrite, and droplets from primary sulfide melt (Nisterenko, this volume), are unstable in this process. Sulfide oxidation results in release of copper, which is deposited as native copper in the rocks and is partly carried away with the solutions and deposited in carbonate veins. This process is apparently regulated by the temperature and general effectiveness of contact between sea water and rock. In the case of low-tempera- ture rock alteration of limited intensity (Hole 443), removal of copper from the basalts is subordinate, and copper in carbonate veins is rare.

\section{REFERENCES}

Anderson, T. F., 1973. Oxygen and carbon isotope compositions of altered carbonates from the western Pacific, core 53.0 Deep Sea Drilling Project. Mar. Geol., 15, 169-180.

Brenneke, J. C., 1978. A comparison of the stable oxygen and carbon isotope composition of Early Cretaceous and Late Jurassic carbonates from DSDP Sites 105 and 367. In Lancelot, Y., Seibold, E., et al., Init. Repts. DSDP, 41: Washington (U.S. Govt. Printing Office), pp. 937-956.

Denser, W. G., Degens, E. T., and Stoffer, P., 1978. $\mathrm{O}^{18}$ and $\mathrm{C}^{13}$ contents of carbonates from deep sea drilling sites in the Black Sea. In Ross, D., Neprochnov, Y., et al., Init. Repts. DSDP, 42, Part 2: Washington (U.S. Govt. Printing Office), pp. 617-626.

Douglas, R. G., and Savin, S. M., 1975. Oxygen and carbon isotope analyses of Tertiary and Cretaceous microfossils from Shatsky rise and other sites in the north Pacific Ocean. In Larson, R., Moberly, R., et al., Init. Repts. $D S D P, 32$ : Washington (U.S. Govt. Printing Office), pp. 509-520.

Javoy, M., and Pineau, F., 1977. Composition isotopique du carbone de l'oxygene et de l'hydrogene dans les basalts de la zone FAMOUS. $5^{e}$ Reun. annu. Sci. terre, Rennes, 282.

O'Neil, J. R., Clayton, R. N., and Mayeda, A., 1969. Oxygen isotope fractionation in divalent metal carbonates. $J$. Chem. Phys., 51(12), 5547-5558.

Sheppard, S., Jehl, V., Poty, B., and Weisbrod, A., 1977. Les isotopes de l'oxygene et de l'hydrogene dans le metamorphisme oceanique. $5^{e}$ Reun. annu. Sci. terre, Rennes, 427. 